\title{
Isolation, Identification and Characterization of Keratin degrading microorganisms from Poultry soil and their Feather degradation Potential
}

\author{
Suchitra Godbole*, Jayashri Pattan, Sonal Gaikwad, Tripti Jha
}

Department of Microbiology, Dr. D.Y. Patil College of Arts, Commerce and Science, Sant Tukaram Nagar, Pimpri, Pune411018, India

\begin{abstract}
Keratinolytic microorganisms have a great importance in poultry waste degradation and its bioconversion to compost or animal feed. The aim of this study was to isolate keratin degrading bacteria and fungi from poultry farm soil, and to study their ability to degrade chicken feathers. The poultry farm soil samples were added in basal medium with feathers as a source of carbon and nitrogen. Five bacterial cultures were isolated. Bacteria were grown in basal media with feathers meal and showed feather degrading capacity. Bacterial strains were identified as Aeromicrobium spp., Exiguobacter spp., Marinococcus spp. and Bacillus spp. 1 \& Bacillus spp 2.These bacteria showed keratinolytic enzyme activity in the cell free culture supernatants. The highest biodegradation of feathers was obtained using Aeromicrobium (KD1$72.55 \%)$, among the isolated cultures. Two fungal cultures (F1 and F2) were also isolated by Hair Bait Technique, out of which F1 showed good keratinolytic activity. The good ability of selected microorganisms to degrade feathers can be utilized for their potential biotechnological application in processing of feather waste from poultry industry.
\end{abstract}

Keywords - Feather degrading Bacteria,Characterization, Identification, Keratinase, Poultry waste.

\section{INTRODUCTION}

The day by day increase in consumption of meat received from chicken is causing harsh effect to environment, as the waste from the chicken birds, more particularly the feather are not properly treated. While in nature, the deterioration of feather is slow, generating sulphureous compounds, causing environmental problem. Feathers, which are almost pure keratin proteins, are produced in large amounts and constitute a waste by product at poultry processing plant. A total 5-7 \% weight of mature chicken comprises of feathers. Feather waste is generated in large quantities as a byproduct of commercial poultry processing. Feathers are made up primarily of keratin which is resistance to common proteolytic enzyme such as pepsin, trypsin and papain [1] .World-wide poultry processing plants produce millions of tons of feathers as a waste product annually, which consists of approximately $90 \%$ keratin; the keratin is largely responsible for their high degree of recalcitrance if remain untreated.

Keratin is a major component of hair, feathers and wool and is the most complex of the cytoskeletal intermediate filament proteins of epithelial cells [2]. Keratin is an insoluble protein macromolecule with very high stability and low degradation rate. Keratin is mainly present in hair, feather, nails, wool and horns. High protein content of keratin waste can be used as a good source of protein and amino acids by systematic recycling. The prospective use of keratinases is in diverse applications where keratins should be hydrolyzed, such as the leather and detergent industries, textiles, waste bioconversion, medicine etc. Recycling of feathers can provide a cheap and alternative protein feed stuff. Further this can be used for animal feed and for many other purposes. However, poor digestibility of keratin is a problem in recycling.

Keratinase is an extracellular enzyme used for the bio degradation of keratin. Keratinase is produced only in the presence of keratin substrate. Keratinase attacks the disulfide bond of keratin to degrade it. Some microbes have been reported to produce keratinase in the presence of keratin substrate. Keratinase producing microorganisms have the ability to degrade chicken feather, hair, nails, wool etc. Keratinolytic enzymes are widespread in nature and are produced by several microorganisms including bacteria such as Bacillus sp.[3-8], Fervidobacterium islandicum [9], Elizabethkingia meningoseptica KB042 [10], Pseudomonas aeruginosaKS1[11] and Actinomycetes such as Streptomyces sp. [12-14] and fungi such as Chrysosporium tropicum [15], Trichoderma atroviridae [16], Doratomyces 
microsporus [17]; Paecilomyces marquandii [18]; Scopulariopsis brevicaulis [19]; Alternaria, Paecilomyces, Penicillium, Curvularia and several Aspergillus sp. [20]. Diversity of keratinolytic fungi in soils have been studied and reported [21, 22]

Keratinophilic fungi are generally considered as soil saprophytes. Soil that is rich in keratinous material is most conducive for the growth and occurrence of keratinophilic fungi. Keratin decomposition in soil leads to an increase in carbon, and nitrogen ratio in soil. They are therefore fast growing nonpathogenic keratinophilic fungi which can be utilized for the recycling of keratin in soil and may be exploited for their biotechnological potential in industry.

Keratinase which are produced by these keratinolytic organisms could be used to degrade feather waste and further the digested products could be an excellent material for producing animal feed, fertilizers or natural gas [23]. Use of keratinolytic organisms for feather degradation is an economical, environmentally friendly alternative. Keratinolytic proteases offer considerable opportunity for a low cost technology for biotechnology of poultry feather from pollutant to nutritionally upgraded protein feed for a livestock [24]. Most feather waste is land filled or burnt which involves expense and can cause contamination of air, soil and water. Utilizing poultry feathers as a fermentation substrate in conjunction with keratin degrading microorganisms and enzymatic degradation may be better alternative to improve nutritional value of poultry feathers and reduce environmental waste [25].It would also solve the waste disposal problem of poultry waste and recycling of keratinacious waste would be beneficial financially and environmentally.

Submerged fermentation of poultry waste by microorganism producing keratinase helps in the conversion of non-soluble keratin (feather) into soluble protein or polypeptide[26].These protein byproduct may be used as animal and livestock feed, and as leather filling agents[27]. Keratinase has also emerging application in de-hairing process in leather industry instead of sodium sulphides [28]. In view of above, the present study was aimed to isolate, identify and characterize the kearatin degrading microorganisms from poultry farm soil and study their feather degradation potential.

\section{MATERIALS AND METHODS}

2.1 Chemicals: All Chemicals required for experimental work were of analytical grade, pure and purchased from Himedia laboratory.
2.2 Sample collection: Soil samples were collected from regular feather dumping site of poultry processing farms from outskirts of Pune, in sterilized sampling bottles. The samples were taken from $30 \mathrm{~cm}$ depth from the surface of the soil. The samples were brought to the laboratory and processed for isolation of microorganisms.

\subsection{Processing of chicken feathers and Preparation of feather meal broth}

Chicken feathers were washed thoroughly with tap water and dried. The dried feathers were defatted by soaking in diethyl ether for $24 \mathrm{hrs}$, and washed thoroughly with tap water and distilled water, air dried and cut into small pieces before autoclaving, the processed feathers referred as Feather meal. The medium used for keratinase production contained the following constituents (g/100ml.) - Feather meal $5 \mathrm{gm}, \mathrm{NaCl} 0.005, \mathrm{~K}_{2} \mathrm{HPO}_{4} 0.038, \mathrm{KH}_{2} \mathrm{PO}_{4} 0.04$ $\mathrm{MgCl}_{2} .6 \mathrm{H}_{2} \mathrm{O} 0.02$, Yeast extract $0.01, \mathrm{pH} 7.5$

\subsection{Isolation and screening of keratinolytic bacteria}

Soil suspensions were made with $0.9 \%$ saline and inoculated in feather meal broth and incubated on rotary shaker at room temperature. After visible turbidity was observed, serial dilutions of the culture suspensions were spread on skimmed milk agar plates for selection of protease producing bacteria, as per the method described earlier [29]. The petri plates were incubated at $30^{\circ} \mathrm{C}$ for 24 hours. The isolated bacterial colonies showing zone of clearance on skimmed milk agar were selected for further studies. The isolates were characterized for colony characteristics, morphological characteristics and biochemical characteristics and identified with Bergey's manual of determinative bacteriology.

\subsection{Isolation of keratinolytic fungi}

The keratinophilic fungi were isolated using 'hair baiting techniques' [30]. In this technique sterile Petri plates were half filled with soil and short strand of sterilized chicken feathers were spread over the surface of soil. About 10-12 $\mathrm{ml}$ sterile water was added to Petri plates for the facilitation of fungal spores to germinate. Petri plates were incubated at $30^{\circ} \mathrm{C}$ for 3-4 weeks. After 3-4 weeks the colonies were observed on surface of feathers, were picked up and grown on Potato Dextrose Agar, for purification and identification.

2.6 Production of keratinase Enzyme and feather degradation by bacterial and fungal isolates

Cultivation of the isolated cultures was performed using $250 \mathrm{ml}$ Erlenmeyer flask containing $90 \mathrm{ml}$ of Feather meal broth medium.10ml of overnight grown culture of each isolate were inoculated and incubated on rotary shaker at $150 \mathrm{rpm}$ for 7 days. Control was feather meal broth without any inoculum. Growth was observed for visible turbidity 
and recorded a6 $600 \mathrm{~nm}$, degradation of feathers was visually observed.

\subsubsection{Extraction of Enzyme}

The culture medium was filtered through WhatmannNo.1 Filter paper to remove un-degraded residues. The filtrate was then subjected to centrifugation at $10,000 \mathrm{rpm}$ for 10 min to remove bacterial residue. After centrifugation keratinase activity was determined in supernatant.

\subsubsection{Determination of feather degradation}

The feather degradation was studied according to the method described by Kumar et. al[31]. The five bacterial isolates namely $\mathrm{KD} 1, \mathrm{KD} 2, \mathrm{KD} 3, \mathrm{KD} 4$ and $\mathrm{KD} 5$ were inoculated in feather meal broth with $1 \%$ feathers as the sole source of carbon and incubated on rotary shaker for one week. After one week the residual feathers remained was determined gravimetrically by filtering the culture broth and taking the weight of filter paper before and after filtration. Percent reduction of feathers was calculated from the difference in the initial weight and weight obtained after one week of incubation.

\subsubsection{Assay for keratinase activity:}

Keratinase activity was assayed according to the method of [32].Each culture filtrate was Centrifuged at $5000 \mathrm{rpm}$ for $30 \mathrm{~min} .20 \mathrm{mg}$ feather meal +3.8 Tris $\mathrm{HCl}$ buffer $+0.2 \mathrm{ml}$ supernatant of culture filtrate were taken ; control was kept where $0.2 \mathrm{ml}$ cultures supernatant was replaced with distilled water. the tubes were incubated at $30^{\circ} \mathrm{C}$ for 1 hour then chilled in ice water for 10 minute, filtered and OD was taken at $280 \mathrm{~nm}$.O.D. values were converted into enzyme unit/ $\mathrm{ml}$ Enzyme Units per $\mathrm{ml}$ was calculated by using following formula:

Enzyme Units per $\mathrm{ml}=$ Optical Density $\mathrm{x} 4 \mathrm{x}$ dilution rate $/ 0.01 \times \mathrm{T}$

Where $\mathrm{T}=$ incubation time, $4=$ total volume used.

\subsubsection{Effect of incubation time on growth of isolates}

The effect of incubation time on growth of isolates was determined in feather meal broth for 7 days. Culture samples were added namely KD1, KD2, KD3, KD4, KD5, $\mathrm{F} 1$ and F2 and with one control flask which was without culture. Feather meal broth $100 \mathrm{ml}$ with $1 \mathrm{gm}$ feathers was added with $2 \mathrm{ml}$ overnight culture in each flask ,incubated on rotary shaker $150 \mathrm{rpm}$. OD was taken at $600 \mathrm{~nm}$, every 24 hours, up to 7 days for monitoring growth.

\subsubsection{Effect of different temperatures on keratinase enzyme activity}

The optimum temperature for keratinolytic protease activity was determined by performing the enzyme reaction at incubation temperatures between $30^{\circ} \mathrm{C}$ to $90^{\circ} \mathrm{C} .40 \mathrm{mg}$ feathers+7.5 ml Tris $\mathrm{HCl}$ buffer+0.4 ml supernatant of culture filtrate of each isolate were taken in sterile test tubes, and tubes were incubated at different temperatures $\left(30^{\circ} \mathrm{C}, 40^{\circ} \mathrm{C}, 50^{\circ} \mathrm{C}, 60^{\circ} \mathrm{C}, 70^{\circ} \mathrm{C}, 80^{\circ} \mathrm{C}\right.$, and $\left.90^{\circ} \mathrm{C}\right)$ for 1 hour. After incubation at different temperatures all tubes were chilled in ice water for 10 minute. Filtered \& OD was taken at $280 \mathrm{~nm}$. O.D. values were converted to enzyme unit/ $\mathrm{ml}$.

2.6.6 Effect of different $\mathrm{pH}$ on keratinase enzyme activity

Keratinolytic protease activity was studied in the $\mathrm{pH}$ range of 4 to 9 using $0.2 \mathrm{M}$ Tris- $\mathrm{HCl}$ buffer. $40 \mathrm{mg}$ feathers +7.5 $\mathrm{ml}$ of bufferhaving different $\mathrm{pH}$ from 4-9, to which $0.4 \mathrm{ml}$ supernatant of culture filtrate of each isolate was added. All tubes were incubated at $30^{\circ} \mathrm{C}$ for 1 hour, and then chilled in ice water for 10 minute to stop the enzyme reaction, then filtered \& OD was taken at $280 \mathrm{~nm}$. O.D. values were converted to enzyme unit/ $\mathrm{ml}$.

\section{RESULTS AND DISCUSSION}

Soil samples were inoculated in feather meal broth to obtain bacterial isolates which are feathers degrading and were capable of producing extra cellular keratinase, using feather (keratin) as sole carbon source. After a week of incubation the flasks showed turbidity and disintegration of feathers were observed, (fig 1).

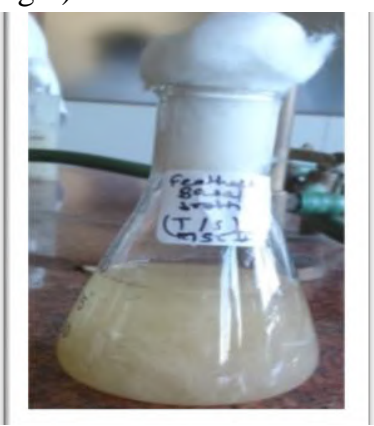

Feather meal Broth

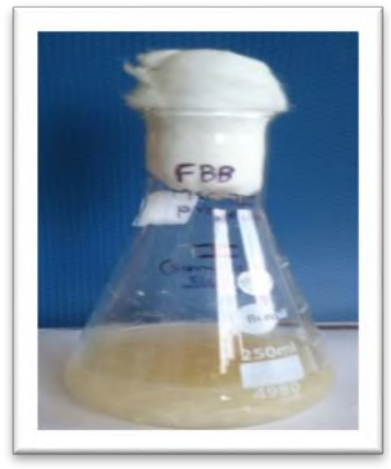

Growth observed 


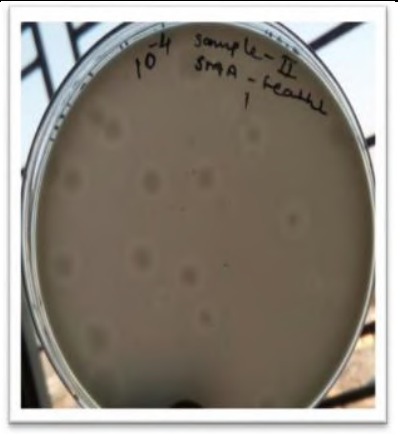

Bacterial Isolates with zone of Clearance on Skim Milk Agar

Fig 1: Growth on Feather meal broth and isolates on Skim milk agar

The same culture suspension was serially diluted up to $10^{-8}$ with normal saline and plated on skim milk agar for, selection of keratinolytic bacteria. The colonies showing zone of clearance were further selected and characterized. Fig 2 shows the fungal isolates by bait technique.

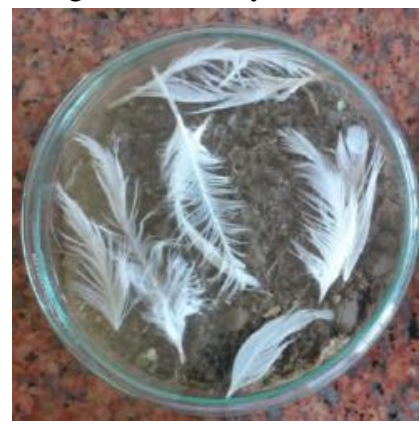

Feathers with poultry soil

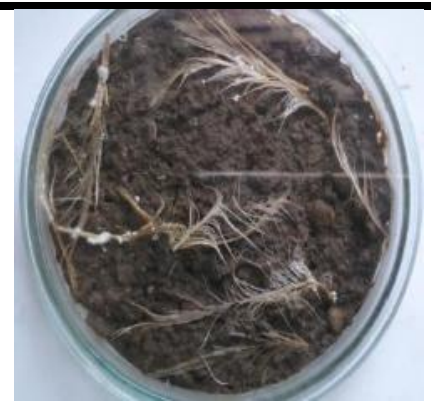

Fungal Growth observed on feathers after 5 weeks

Fig 2: Bait Technique for isolation of keratinolytic Fungi

Colonies showing zone of clearance on skim milk agar were counted. Table 1 shows the bacterial counts of soil samples 1 and 2 on Nutrient agar plates and Skim milk agar plates. The colonies showing zone of clearance were selected and observed for colony characteristics, morphological characteristics and biochemical characteristics. Based on colony characteristics five types of bacterial isolates were obtained, these isolates were designated as $\mathrm{KD} 1, \mathrm{KD} 2$, KD3, KD4 and KD5.

Table.1: Bacterial Count on Nutrient Agar (NA) and Skim Milk Agar (SMA)

\begin{tabular}{|c|c|c|c|c|c|c|}
\hline & & $\begin{array}{l}\text { NA Plates } \\
\text { CFU/ml }\end{array}$ & & & $\begin{array}{l}\text { SMA plates } \\
\text { CFU/ml }\end{array}$ & \\
\hline Dilutions & $10^{-4}$ & $10^{-6}$ & $10^{-8}$ & $10^{-4}$ & $10^{-6}$ & $10^{-8}$ \\
\hline $\begin{array}{c}\text { Bacterial Count, Soil } \\
\text { sample1 }\end{array}$ & $\begin{array}{r}21 x \\
10^{5}\end{array}$ & $12 \times 10^{6}$ & $4 \times 10^{8}$ & $4 \times 10^{4}$ & $1 \times 10^{6}$ & $1 \times 10^{8}$ \\
\hline $\begin{array}{c}\text { Bacterial Count, Soil } \\
\text { sample } 2\end{array}$ & $\begin{array}{c}14 x \\
10^{5}\end{array}$ & $8 \times 10^{6}$ & $2 \times 10^{8}$ & $3 \times 10^{5}$ & $2 \times 10^{6}$ & $1 \times 10^{8}$ \\
\hline
\end{tabular}

Table 2 shows the colony characteristics of the bacterial isolates. The morphological characteristics of the isolates are shown in Table 3.The results of biochemical characterization of the bacterial isolates are shown in Table 4.On the basis of colony, morphological and biochemical characteristics and reference to Bergey's manual of determinative bacteriology the five cultures $\mathrm{KD} 1, \mathrm{KD} 2, \mathrm{KD} 3 \mathrm{KD} 4$ and $\mathrm{KD} 5$ were identified up to genus level and were identified as Aeromicrobium Sp., ExiguobacterSp., MarinococcusSp,Bacillus Spl and Bacillus Sp2.Most of the studies on isolation of keratinolytic organisms have resulted in isolation of Bacillus spp, however in the present study the isolated bacteria Aeromicrobium, Exiguobacter and Marinococcus have been reported for the first time. 
Table.2: Colony and Morphological Characteristics of the Bacterial Isolates

\begin{tabular}{|c|c|c|c|c|c|c|c|}
\hline $\begin{array}{c}\text { Colony } \\
\text { characteristics }\end{array}$ & Shape & Size & Colour & Margin & Opacity & Consistency & Elevation \\
\hline Isolates KD1 & Irregular & Pin point & Cream & Irregular & Opaque & Sticky & Flat \\
\hline KD2 & Irregular & Pin point & Orange & Irregular & Opaque & Sticky & Flat \\
\hline KD3 & Circular & Pin point & Orange & Regular & Opaque & Sticky & Convex \\
\hline KD4 & Circular & $2-4 \mathrm{~mm}$ & Cream & Regular & Opaque & Sticky & Flat \\
\hline KD5 & Circular & $3-5 \mathrm{~mm}$ & White & Regular & Opaque & Sticky & Flat \\
\hline
\end{tabular}

Table.3: Morphological characteristics of the isolates

\begin{tabular}{|l|l|l|l|l|l|}
\hline $\begin{array}{l}\text { Morphological } \\
\text { Characteristics } \\
\text { of the isolates }\end{array}$ & KD1 & KD2 & KD3 & KD4 & KD5 \\
\hline $\begin{array}{l}\text { Gram } \\
\text { Reaction }\end{array}$ & $\begin{array}{l}\text { Gram + ve } \\
\text { short rods }\end{array}$ & $\begin{array}{l}\text { Gram + ve } \\
\text { long rods }\end{array}$ & $\begin{array}{l}\text { Gram +ve } \\
\text { Coccobacilli }\end{array}$ & $\begin{array}{l}\text { Gram +ve } \\
\text { rods }\end{array}$ & $\begin{array}{c}\text { Gram +ve } \\
\text { rods }\end{array}$ \\
\hline Motility & Non-motile & Motile & $\begin{array}{l}\text { Actively } \\
\text { motile }\end{array}$ & $\begin{array}{l}\text { Actively } \\
\text { motile }\end{array}$ & Motile \\
\hline $\begin{array}{c}\text { Endospore } \\
\text { Staining }\end{array}$ & $\begin{array}{l}\text { Non spore } \\
\text { forming }\end{array}$ & $\begin{array}{l}\text { Non spore } \\
\text { forming }\end{array}$ & $\begin{array}{l}\text { Non spore } \\
\text { forming }\end{array}$ & Spore forming & Spore forming \\
\hline
\end{tabular}

Table.4: Biochemical Characterization of the Bacterial Isolates

\begin{tabular}{|c|c|c|c|c|c|}
\hline Sugar & KD1 & KD2 & KD3 & KD4 & KD5 \\
\hline Glucose & + & + & + & + & + \\
\hline Cellulose & - & - & - & - & - \\
\hline Fructose & - & + & + & + & + \\
\hline Raffinose & - & - & - & - & - \\
\hline Galactose & - & + & - & - & - \\
\hline Maltose & + & + & + & + & + \\
\hline Sucrose & - & + & - & + & + \\
\hline Mannitol & - & - & - & - & - \\
\hline Arabinose & - & - & - & - & - \\
\hline Lactose & - & - & - & - & - \\
\hline Xylose & - & - & - & - & - \\
\hline Oxidase & + & - & - & + & + \\
\hline Catalase & + & + & + & + & + \\
\hline Citrate utilization & - & - & - & - & - \\
\hline Gelatinase & - & + & - & - & - \\
\hline Nitrate reduction & - & + & - & - & - \\
\hline Caesin hydrolysis & + & + & + & + & + \\
\hline Starch hydrolysis & + & + & + & + & + \\
\hline Identified organism & $\begin{array}{c}\text { Aeromicrobium } \\
\text { spp }\end{array}$ & $\begin{array}{c}\text { Exiguobacter } \\
\text { spp }\end{array}$ & $\begin{array}{c}\text { Marinococcus } \\
\text { spp. }\end{array}$ & $\begin{array}{l}\text { Bacillus } \\
\text { spp } 1\end{array}$ & $\begin{array}{c}\text { Bacillus } \\
\text { spp. } 2\end{array}$ \\
\hline
\end{tabular}

Out of five bacterial isolates, two isolates have been identified as Bacillus spp. as also reported by others[24,35]. In our study all the bacterial isolates have been found to be gram positive, whereas others have reported keratinolytic activity by gram negative bacteria [33]. Two fungal cultures, F1 and F2 were also isolated by bait technique and were found to grow on feather meal broth. However they could not be identified. Many researchers have worked on isolation and characterization of bacteria from poultry processing wastes and shown to degrade feathers, hair or 
wool, but the optimization for industrial production of keratinases still remains to be done.

Table 5 shows the results of feather degradation experiment.
The result shows that KD1 was the most effective and showed $72.55 \%$ feather degradation, it is followed by KD270.59\%, KD5-60\%, KD4- 58.82\% and KD3- 55\%.

Table.5: Feather degradation by the isolated bacterial cultures

\begin{tabular}{|c|c|c|c|}
\hline $\begin{array}{c}\text { Culture sample inoculated in } \\
\text { Feather Meal Broth (FMB) }\end{array}$ & $\begin{array}{c}\text { Initial weight } \\
\text { of filter } \\
\text { paper with } \\
\text { feathers(gm) }\end{array}$ & $\begin{array}{c}\text { Final weight of } \\
\text { filter paper } \\
\text { with } \\
\text { feathers(gm) }\end{array}$ & $\begin{array}{c}\text { \% reduction of } \\
\text { feathers }\end{array}$ \\
\hline KD1 (Aeromicrobium spp.) & 1.02 & 0.28 & $72.55 \%$ \\
\hline KD2 (Exiguobacter spp.) & 1.02 & 0.3 & $70.59 \%$ \\
\hline KD3 (Marinococcus spp.) & 1.02 & 0.45 & $55.88 \%$ \\
\hline KD4( Bacillus spp. 1) & 1.02 & 0.42 & $58.82 \%$ \\
\hline KD5( Bacillus spp. 2 $)$ & 1.02 & 0.40 & $60.78 \%$ \\
\hline
\end{tabular}

Effect of incubation time on growth of microbial isolates is shown in figure 3. KD4 and KD5 isolates entered stationary phase after 48 hrs, KD3 and KD1 on $3^{\text {rd }}$ day, while KD 2 on $4^{\text {th }}$ day. After day 5 all isolated entered the decline phase. The highest keratinase activity was shown by $\mathrm{KD} 1(18 \mathrm{U} / \mathrm{ml})$, followed by $\mathrm{KD} 2, \mathrm{KD} 3, \mathrm{KD}$, and KD4, as shown in fig 4.

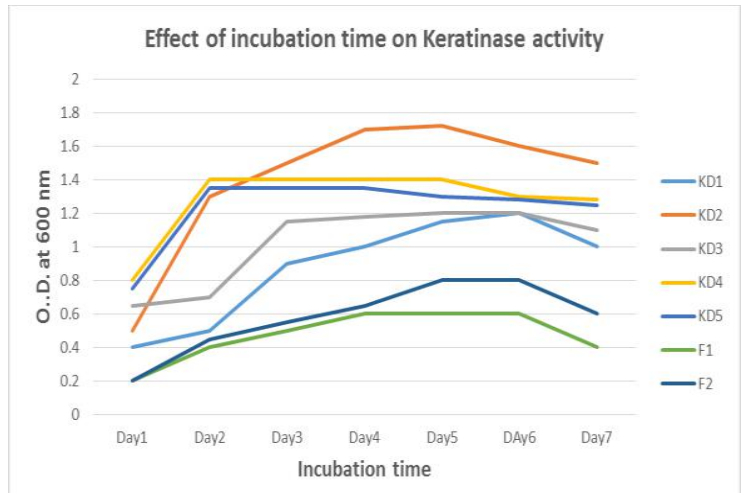

Fig.3: Effect of Incubation Time on Growth of Isolates

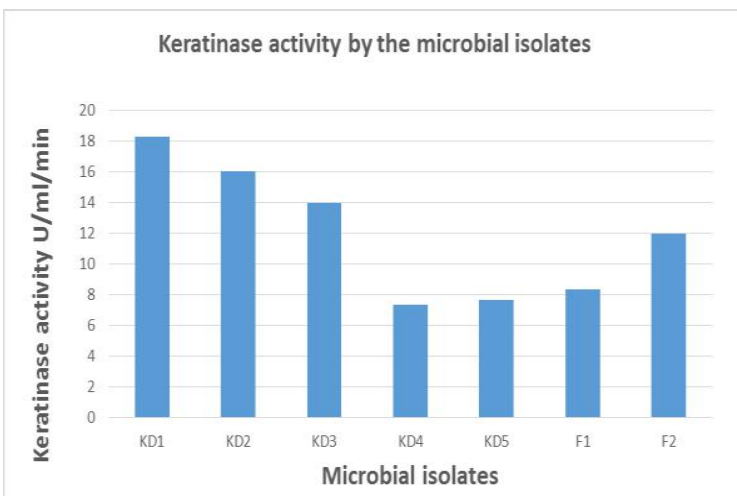

Fig.4: Keratinase Activity with The Isolated Cultures
Whereas other workers have reported maximum keratinase activity of $13.6 \mathrm{U} / \mathrm{ml}$ and $8.8 \mathrm{U} / \mathrm{ml}[34]$. F2 fungal isolate showed Keratinase activity of $12 \mathrm{U} / \mathrm{ml}$.

Fig.5 shows the result of the effect of different $p \hat{H}$ on keratinase activity, it was observed that the optimum $\mathrm{pH}$ for the bacterial isolates $\mathrm{KD} 1, \mathrm{KD} 3, \mathrm{KD} 4, \mathrm{KD} 5$ and fungal isolates F1\& F2 was 9, whereas for KD2 it was 7.Most of the isolates in this study have shown higher activity at alkaline $\mathrm{pH}$ as also reported by Inamdar et.al [36]. Keratinase from the most of the bacteria, actinomycets and fungi have $\mathrm{pH}$ optima in neutral to alkaline range. Enzyme with optimum activity at alkaline $\mathrm{pH}$ has definite advantages in application, both in degradation of feathers as well as in leather industry.

The effect of temperature on keratinase activity is shown in figure 6. It was observed that the optimum temperature was $30^{\circ} \mathrm{C}$ for all the bacterial isolates, while others have reported optimum temperature of $40 \pm 20 \mathrm{C}$ [14]. For F1 and $\mathrm{F} 2$ optimum temperature was found to be $50^{\circ} \mathrm{C}$.

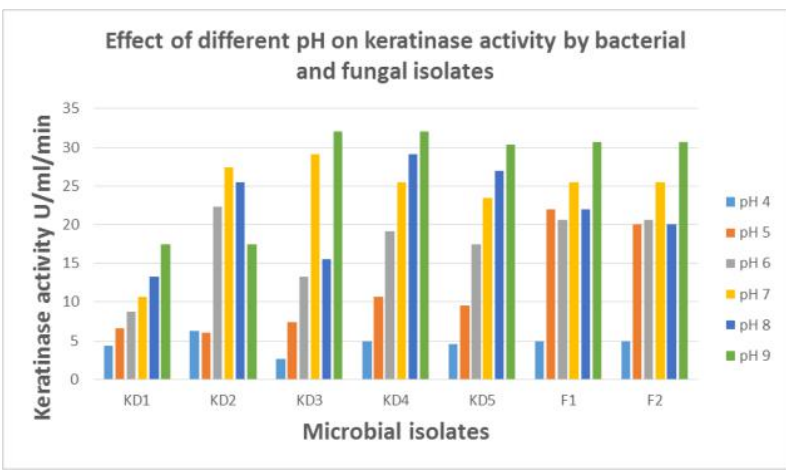

Fig.5: Effect of pH on Keratinase Activity 
Effect of Temperature on keratinase activity by microbial isolates.

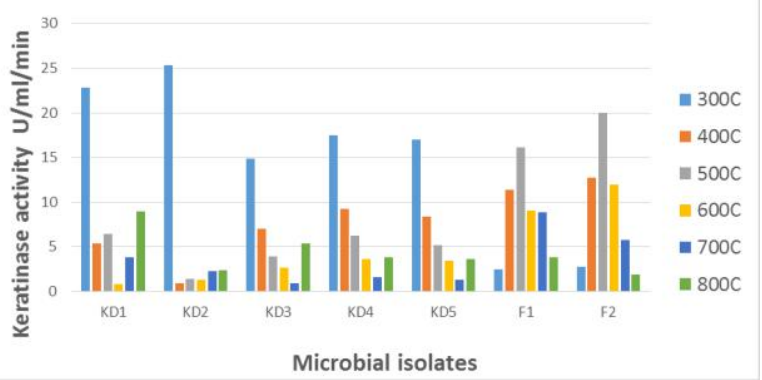

Fig.6: Effect of Temperature on Keratinase Activity of The Isolates

Feather degradation to the range of $70-72 \%$ by newly isolated Aeromicrobium and Exiguobacter spp. even under unoptimised condition can be further exploited for efficient degradation of feathers under optimised conditions.

In soil feathers are degraded by a consortium of bacteria and fungi, which act in synergy or compete for keratin.

Biodegradation by microorganisms possessing keratinolytic activity represents an alternative attractive method for improving the nutritional value for keratin wastes, as it offers cheap and mild reaction conditions for the production of valuable products there have been some reports on microorganism capable of degrading keratinous wastes.Further optimization of keratinase production and characterization of the keratinase would be helpful in application of keratinases on a large scale for degradation of keratin containing wastes.

\section{CONCLUSION}

In the present study five bacterial cultures were isolated producing keratinase from habitats where keratin containing substrate were disposed in natural conditions. The five bacterial isolates were characterized and identified based on colony morphology, growth characteristics and biochemical characteristics. They were identified as belonging to genera Aeromicrobium spp., Exiguobacter spp., Marinococcus spp., Bacillus spp1, Bacillus spp, respectively. The isolate Aeromicrobium spp. (KD1) shows the highest feather degradation of $72.5 \%$.The optimum temperature was $30^{\circ} \mathrm{C}$ for all the bacterial isolates, whereas for $\mathrm{F} 1$ and $\mathrm{F} 2$ it was $50^{\circ} \mathrm{C}$. The optimum $\mathrm{pH}$ for bacterial and fungal isolates found to be 9except for KD2 it was 7.Feather degradation to the extent of $70-72 \%$ by newly isolated Aeromicrobium and Exiguobacter spp. even under unoptimised condition can be further exploited for efficient degradation of feathers under optimized conditions.

The ability of newly isolated bacteria to degrade feathers can be utilized for their potential biotechnological application in processing of feather waste from poultry industry. For the evaluation of biotechnological application of keratinase, however require more detailed understanding of the factors that enable this enzyme for complete degradation of native keratinase substrate. Therefore additional research will need to done for purification, characterization of keratinase, studying kinetics of enzymes, testing from various range of substrate, effect of inhibitors, and inducer on enzyme activity, submerged state fermentation for large scale production of keratinase. Further studies can be focused on whether consortium of bacteria and fungi can be utilized for feather degradation, rather than individual cultures for enhanced keratinolytic activity.

\section{ACKNOWLEDGEMENT}

The authors wish to thank the principal and the management of the college for providing the necessary facilities for carrying out this research.

\section{REFERENCES}

[1] Gupta R. And Ramnani P. "Microbial keratinases and their prospective applications an overview, ApplMicrobiol Biotechnol", 2006, vol 70,pp 21-33

[2] Latkowski JM, Freedberg IM. "Epidermal cell kinetics, epidermal differentiation, and keratinization”. In: Freedberg, I.M., Eisen, A.Z., Wolff, K. (eds). (1999). Fitzpatrick's Dermatology in General Medicine. McGraw- Hill, New York, pp. 133-144

[3] Korkmaz H. Hur H. ,Dincer S. “ Characterization of alkaline keratinase of Bacillus licheniformis strain HK-1 frompoultry waste" Ann. Microbiol.2004, vol 54,pp $201-211$

[4] Ionata E. ,Canganella F. ,Bianconi G. ,Benno Y. ,Sakamoto M. ,Capasso A. , Rossi M. , La Cara F. “ A novelkeratinase from Clostridium sporogenesbv. peenavoransbv. nov., a thermotolerant organism isolated from solfataric muds" Microbiol. Res.2008,vol 163, pp 105- 112.

[5] Rai S.K, Konwarh R., Mukherjee A.K., "Purification, Characterization and biotechnological application of an alkaline $\beta$-keratinase produced by Bacillus subtilis RM-01 in solid-state fermentation using chickenfeather as substrate" Biochem. Eng. J. 2009, vol 45, pp 218-225

[6] Mazotto A.M. , Cristina A.N. , De Melo N. , Macrae A. ,Rosado A., Peixoto R., Cedrola S.M.L, Couri S. , ZingaliR.B. ,Villa A.L.V. , Rabinovitch L. ,Chaves 
J.Q. , Vermelho A.B., "Biodegradation of feather waste by extracellularkeratinases and gelatinases from Bacillus Spp" World. J. Microbiol. Biotechnol. 2010, vol 27, pp 1355-1365

[7] Shrinivas D. And Naik G. R. "characterization of alkaline thermostable keratinolyticprotease fromthermoalkalophilicbacillus haloduransjb 99 exhibiting dehairing activity", Int. Biodeterioation\& Biodegradation, 2011,vol 65(1), pp 29-35

[8] Ramnani P., Singh R. And Gupta R. “ keratinolytic potential of bacillus licheniformis rg1: structural and biochemical mechanism of feather degradation", can J. Microbiol, 2005,vol 51, pp 191-196

[9] Nam G.W., Lee D.W., Lee H.S., Lee N.J., Kim B.C., Choe E.A., Hwang J.K., Suhartono M.T., Pyun R. “ Nativefeather degradation by Fervidobacteriumislandicum AW-1, a newly isolated keratinase-producing thermophilicanaerobe", Arch. Microbiol. 2002,vol 178,pp 538-547

[10] Nagal S., Jain P.C. "Production of feather hydrolysate by Elizabethkingiameningoseptica KB042 (MTCC 8360 ) in submerged fermentation", Indian J. Microbiol. 2010, S41-S45

[11] Sharma R., Gupta R. "Thermostable, Thiol activated keratinase from Pseudomonas aeruginosa - KS1 forprospective applications in Prion decontamination", Research J. Microbiol.2010, vol5, pp 954-965

[12] MabroukM.E.M.,"Feather degradation by a new keratinolytic Streptomyces sp. MS2",World.J.Microbiol.Biotechnol.2008, vol 24, pp 2331-2338

[13] Syed D.G., Lee J.C. ,Li W.J., "Production, Characterization and application of keratinase from Streptomycesgulbargensis", Bioresource. Technol. 2009, vol 100, pp 1868-1871

[14] Shilpa Ashok Jani, RishitSoni, Hetal Patel, Brinda Prajapati and Gayatri Patel." Screening, isolation and characterization of keratin degrading actinomycetes: Streptomyces sp. andSaccharothrixxinjiangensi and analyzing their significance for production of keratinolytic protease and feed grade amino acids". Int. J. Curr. Microbiol. App. Sci.2014,vol 3(9),pp 940-955

[15] Maruthi Y.A., Aruna Lakshmi, Ramakrishna Rao, "Chrysosporiumtropicum - A potential feather/hair waste degrading keratinophilic fungi”, J. Environ. Res. Manage.2011,vol 2,pp 014- 018
[16]Cao L. , Tan H. ,Liu Y. , Xue X. , Zhou S., "Characterization of a new keratinolytic Trichoderma atroviride strain F6 that completely degrades native chicken feather", The society for Applied Microbiology. Lett. Appl. Microbiol. 2008, vol 46,pp 389-394

[17] Gradisar H., Friedrich J., Krizaj I., Jerala R.; Similarities and specificities of fungal keratinolytic proteases: comparison of keratinases of Paecilomycesmarquandiiand Doratomycesmicrosporus to some known proteases, Appl. Environ. Microbiol. 2005,vol 71, pp 3420-3426

[18] Anbu P. , Gopinath S.C.B, Hilda A. ,Lakshmipriya A. , Annadurai G. " Purification of keratinase from poultry farm isolate Scopulariopsisbrevicaulis and statistical optimization of enzyme activity", Enzyme Microb. Technol.,2007,vol 36, pp 639-647

[19] Rodrigues N.M. Ledesma C.T., Cirena D.V. "New feather - degrading filamentous fungi",Microb. Ecol. 2008,vol 56,pp 13-17

[20] Thoomatti Sudharsan Anitha and PeramachiPalanivelu."Production and characterization of keratinolytic protease(s)from the fungus, Aspergillus parasiticus". International Journal of Research in Biological Sciences 2012, vol 2(2), pp 87-93

[21] Neetu Jain, Meenakshi Sharma. "Biodiversity of Keratinophilic Fungal Flora in University Campus, Jaipur, India”. Iranian J Publ Health, 2012, Vol. 41(11), pp.27-33

[22] Tarun Kumar Kumawat, Vishnu Sharma, Ruchi Seth and Anima Sharma, " Diversity of Keratin Degrading FungalFlora in Industrial area of Jaipur and Keratinolytic Potential of Trichophyton Mentagrophytes and MicrosporumCanis", International Journal of Biotechnology and Bioengineering Research.,2013, Vol 4( 4), pp. 359364

[23] Tamilmani P. Umamaheswari A, Vinayagam A and Prakash B. "Production of extracellular feather degrading enzyms by Bacillus licheniformis isolated from poultry farm soil in NamakalDistrick (Tamilnadu)",International Journal of Poultry Science, 2008, vol 7 (2), p184-188

[24] Vigneshwaran C., Shanmuga S. and Satish kumar T. “ screening and characterization of keratinase from Bacillus licheniformis isolated from Namakkal poultry farm”.2010,vol 2(4), pp 89-96 
[25] VeslavaMatikeviciene, DanuteMasiliuniene and SauliusGrigiskis." Degradation of keratin containing waste by Bacteria with keratinolytic activity", Environmental Technology Resources Proceeding of the $7^{\text {th }}$ International Scientific and Practical Conference. 2009, Volume 1

[26] Suntornsuk, W. and L. Suntornsuk "Feather degradation by Bacillus sp FK 46 in submerged Cultivation". Bioresour. Technol.2003,vol 86,pp 239243

[27] Sastry T.P., Sehgal P.K, Gupta B and Mahendra Kumar "Solublised keratins as Novel filler in the retaining of upper leather", Leather Science.1986,vol 33,pp 345-359

[28] Alexandre, J.M., O.B. Walter, G. Renata, D. David, P.H. Joao Antonio and T. Carlos "Novel keratinase from Bacillus subtilis S14 exhibiting remarkable dehairing capabilities". Appl. Environ. Microbiol., 2005,vol71,pp 594-596

[29] ZerdaniIlham, faid M. and Malik A. "Feather wastes digestion by new isolated strain Bacillus sp. In Morocco".African J. Biotechnology.2004,pp 67-70

[30] Sharma R. And Rajak R. C., " keratinophilic fungi: nature's keratin degrading machines- their isolation, Identification and ecological role", Resonance, 2003,vol 8,pp 28-40

[31] Kumar A. J. M., Lakshmi A. ,Sangita R.V. “ Isolation and characterization of fearther degrading bacteria from poultry waste". Journal of Research in Biology.2012,vol 2(7),pp 676- 682

[32] Ponnusamykonar Poovendran, VenkitasamyKalaigand, VidhyaKamalaseKanan, E. Jamuna rani and EliyaperumalPoongunran "A study of feather keratin degradation by Bacillus licheniformisand quantification of keratinase enzyme produced". J. Microbiol. Biotech. Res., 2011,vol 1 (3),pp 120-126

[33] Kulkarni S.A. and Jadhav A.R. Isolation and Characterization of Keratinolytic Bacteria from Poultry farm soils. International Research Journal of Biological Sciences Vol. 3(7), 29-33, July (2014)

[34] Bharti Agarwal Mittal Dalal. Screening and characterization of keratinase enzyme obtained from keratin degrading microorganisms isolated from Sanjan poultry waste dumping soil. European Academic Research,2015, vol2,(11),pp 13986-13994

[35] Femi-Ola, T. O., Akinbobola, O. S. and Oluwaniyi, T. $\mathrm{T}$. Isolation and characterization of feather degrading bacteria from poultry soil. Agric. Bio. J.N.Am.2015, Vol 6(5), pp 146-154

[36] Areeb Inamdar, SaheraNasreen and Rashiqua Siddiqui, Screening And Production Of Extra Cellular Feather Degrading Enzyme From Bacterial Isolates, Indian J.L. Sci. 2012,vol 1(2),pp 19-24 